\title{
Let her lead: acknowledging women leadership in the time of pandemic
}

Deixe-a liderar: reconhecendo a liderança feminina na época da pandemia

Dejemos que lidere: reconociendo el liderazgo de las mujeres en tiempos de pandemia

\author{
Christian F. Gonzales \\ Christian.f.Gonzales@isu.edu.ph \\ Isabela State University - Cauayan Campus - Philippines \\ https://orcid.org/0000-0002-7712-359X
}

\begin{abstract}
Political leadership is usually understood as an arena dominated by men. Despite various campaigns across the globe for women empowerment, patriarchy is still the dominant trend in our society. There are still a huge number of people who cannot admit the fact that women can lead. This study argues that women leadership must be acknowledged. In so doing, this study is composed of three parts. The first part discusses politics of the sexes. The second part presents how various women world leaders do an excellent job in their country's pandemic response. Finally, the third part reflects on how the world should acknowledge that leadership chooses no gender and that women, just like men, are also capable to lead excellently.
\end{abstract}

Keywords: Women leadership; Covid-19 crisis; Angela Merkel; Jacinda Ardern; Tsai Ing-wen

\section{RESUMO}

A liderança política é geralmente entendida como uma arena dominada por homens. Apesar de várias campanhas em todo o mundo para o empoderamento das mulheres, o patriarcado ainda é a tendência dominante em nossa sociedade. Ainda existe um grande número de pessoas que não conseguem admitir o fato de que as mulheres podem liderar. Este estudo argumenta que a liderança das mulheres deve ser reconhecida. Ao fazer isso, este estudo é composto de três partes. A primeira parte discute a política dos sexos. A segunda parte apresenta como várias mulheres líderes mundiais fazem um excelente trabalho na resposta à pandemia de seus países. Por fim, a terceira parte reflete sobre como o mundo deve reconhecer que a liderança não escolhe gênero e que as mulheres, assim como os homens, também são capazes de liderar de maneira excelente.

Palavras-chave: Liderança feminina; Crise Covid-19; Angela Merkel; Jacinda Ardern; Tsai Ing-wen

\section{RESUMEN}

El liderazgo político suele entenderse como un escenario dominado por hombres. A pesar de varias campañas en todo el mundo para el empoderamiento de las mujeres, el patriarcado sigue siendo la tendencia dominante en nuestra sociedad. Todavía hay una gran cantidad de personas que no pueden admitir el hecho de que las mujeres pueden liderar. Este estudio sostiene que se debe reconocer el liderazgo de las mujeres. Al hacerlo, este estudio se compone de tres partes. La primera parte analiza la política de los sexos. La segunda parte presenta cómo varias mujeres líderes mundiales hacen un excelente trabajo en la respuesta a la pandemia de sus países. Finalmente, la tercera parte reflexiona sobre cómo el mundo debe reconocer que el liderazgo no elige ningún género y que las mujeres, al igual que los hombres, también son capaces de liderar de manera excelente.

Keywords: Liderazgo de mujeres; Crisis de Covid-19; Angela Merkel; Jacinda Ardern; Tsai Ing-wen

\section{INTRODUCTION}

Political leadership is usually understood as an arena dominated by men. While there are already women leaders who shine in the global political sphere, there still seems a huge number of people who cannot accept the fact that women can lead. The cliché and misconceptions that women are weak, dependent to men, lacks initiative, not iron-fisted and the like can still be heard here and there. Further, women's leadership is often discussed in terms of the "double bind", that is, when female leaders follow social gender role norms and display feminine attitudes, they are perceived as 
weak, ${ }^{1}$ but they risk being perceived as offensive if they observe organizational position norms and display masculine behaviors. ${ }^{2}$

In 2020, the Reykjavik Index for Leadership found out that not even one among the G7 countries $^{3}$ expressed full satisfaction with the idea of a woman as President or Prime Minister or even a CEO of a major corporation. ${ }^{4}$ This implies that despite various campaigns across the globe for women empowerment, the idea of women as leaders is not yet fully accepted. It became normal for leadership attitudes to revert to masculine behavior stereotypes, resulting in implicit gender bias. $^{5}$

One study shows that women are less politically active, educated, and successful than men, and this gender difference in political engagement has implications for political participation. ${ }^{6}$ Meanwhile, in another recent study, it was discovered that women appear to neglect their own real political preferences in favor of the dominant, male-oriented view of politics. ${ }^{7}$

According to the United Nations Women Report for the year 2021, only 22 countries from among its member-countries have or had women as Heads of State or Government, and 119 countries have never had a woman leader. This goes to show that gender representation in the highest positions of authority will not be achieved for another 130 years if current trends continue. ${ }^{8}$

But while underrepresented, women world leaders are actually doing excellently in their jurisdictions. Their performance is at par with their male counterparts. Various studies even suggest that they outperform men world leaders during the pre-Covid-19 and the Covid-19 crisis.

This study argues that women leadership in the time of pandemic must be acknowledged. In so doing, this study is composed of three parts. The first part discusses politics of the sexes. The second part presents how various women world leaders do an excellent job heading their countries pandemic response. Finally, the third part is a reflection of how the world should acknowledge that leadership chooses no gender and that women, just like men, are capable to lead excellently.

\section{POLITICS OF THE SEXES}

Etymologically speaking, politics comes from the word politike, which means "a matter pertaining to public affairs, concerning the governance of a country or the people." 9 To simply put, it refers to the science and art of government. ${ }^{10}$ Hence, it concerns itself with the activities

\footnotetext{
${ }^{1}$ Eagly, Alice H. "Sex differences in social behavior: A social-role interpretation", Psychology Press, 2013.

${ }^{2}$ Gelaye Debebe and Sandy Nunn, eds., "Navigating the double bind: Transformations to balance contextual responsiveness and authenticity in women's leadership development", Cogent Business \& Management, 4:1 (2017): 1-

28, DOI: https://doi.org/10.1080/23311975.2017.1313543

${ }^{3}$ The G7 Countries are the United Kingdom, Canada, United States of America, Italy, France, Germany, and Japan.

${ }^{4}$ Kantar, "The Reykjavik Index for Leadership 2020/2021,” accessed April 5, 2021,

https://www.kantar.com/campaigns/reykjavik-index/.

${ }^{5}$ Christine Ro, "Why do we still distrust women leaders?" BBC, January 19, 2021, https://www.bbc.com/worklife/article/20210108why-do-we-still-distrust-women-leaders.

${ }^{6}$ Sidney Verba, Nancy Burns,and Kay Lehman Schlozman, "Knowing and Caring about Politics: Gender and Political Engagement.” The Journal of Politics, 59 no. 4 (1997): 1051-1072, http://www.jstor.org/stable/2998592

7 Monica Ferrín, Marta Fraile, Gema García-Albacete, and Raul Gómez, "The gender gap in political interest revisited." International Political Science Review, 41 no. 4: 473-489. https://doi.org/10.1177/0192512119860260

8 UN Women, "Facts and figures: Women's leadership and political participation," accessed April 5, 2021, https://www.unwomen.org/en/what-we-do/leadership-and-political-participation/facts-and-figures

${ }^{9}$ Online Etymology Dictionary, s.v. "Politics,"

https://www.etymonline.com/word/politic?ref=etymonline crossreference\#tetymonline_v_17575

${ }^{10}$ Merriam-Webster (Merriam-Webster, Incorporated), s.v. "Politics," https://www.merriamwebster.com/dictionary/politics
} 
associated with the governance of a country, state, nation or other areas, especially the debate or conflict among individuals or groups having or hoping to achieve power.

The word politics was used in Kate Millet's Sexual Politics to refer to power-structured relationships, or structures in which one group of people is dominated by another. ${ }^{11}$ It was used in discussing the sexes since such a word is extremely useful in describing the true essence of their (male and female) relative status, both historically and currently. ${ }^{12}$ Politics then has something to do with the concept of power relationships in relation to its traditional formal definition. Personal contact and interaction between members of well-defined and cohesive communities, such as races, castes, classes, and sexes, can be used to describe these power relationships.

Throughout history, politics became a general control of one collectivity over another collectivity. It has been a relationship of domination and subordination. And in our society, we can easily see that the one of the fundamental concepts of power is the sexual domination of men over the subordinated women. This is because our society, just like in the past, has been a patriarchy. Thus, it is saddening to hear misogynistic remarks such as the recent pronouncement made by the Philippine President, Rodrigo Roa Duterte, that presidency [leadership] was no job for a woman because of their emotional differences to men. ${ }^{13}$

Feminist advocates and academics have contextualized and challenged these male dominance trends, pointing out that male dominance is neither normal nor desirable. ${ }^{14}$ In order for this concept of domination and subordination to be cut off or for patriarchy to end, it was suggested that a sexual revolution in the context of sexual politics must take place. The goal of this sexual revolution is to eliminate both the male supremacy ideology and the conventional socialization that supports it in terms of status, role, and temperament. ${ }^{15}$

As a consequence, women have built a society based on feminist principles so that men will be forced to live in the community very different from the present. ${ }^{16}$ A related event here is the reexamination of masculine and feminine characteristics, as well as a re-evaluation of their human desirability. Women is no longer identified as an annoying minority force to be put down and to be perfectly controlled by the dominant men. ${ }^{17}$

As observed in various societies, today's women are unstoppable. Their power and popularity are on the rise. ${ }^{18}$ Women are constantly demanding a new world, one which allows them to do and be anything they want, and women are developing the structures that allow them to do so.

\section{HOW WOMEN LEADERS HANDLE THE PANDEMIC}

Men political leaders portray themselves as strong leaders who will defend their people from both internal and external threats while also promising economic stability. This portrayal can be

\footnotetext{
${ }^{11}$ Kate Millet, Sexual Politics (Illinois: University of Illinois Press, 1969), 23.

12 Ibid. 24.

13 Karen Lema, "Philippines' Duterte says presidency no job for a woman," Reuters, January 14, 2021, https://www.reuters.com/article/us-philippines-duterte-idUSKBN29J21U

${ }^{14}$ Georgina Waylen, Karen Celis, Johanna Kantola, and S. Laurel Weldon, eds., The Oxford Handbook of Gender and Politics (Oxford: Oxford University Press, 2013), 3. DOI: 10.1093/oxfordhb/9780199751457.013.0034

${ }^{15}$ Kate Millet, Sexual Politics, 62.

${ }^{16}$ Roxanne Dunbar, "Female Liberation as the Basis for Social Revolution," in Sisterhood is Powerful, ed R. Morgan ( New York: Vintage Books A Division of Random House, 1970), 477-494.

17 Wagner, Claire. "Sexual Politics." The Australian Quarterly 43, no. 4 (1971): 121-25. Accessed April 5, 2021. doi:10.2307/20634474.

${ }^{18}$ Morgan, B. (2021, March 7). 15 Of The World's Most Inspiring Female Leaders. Forbes.

https://www.forbes.com/sites/blakemorgan/2021/03/07/15-of-the-worlds-most-inspiring-female-leaders/?sh=15c8adef3e6e
} 
seen as a type of protective masculinity, ${ }^{19}$ in which male leaders use traditional notions of the male head of household and breadwinner who protects and cares for his family to show that they possess the requisite masculine characteristics to defend their nation. ${ }^{20}$ Protective femininity, on the other hand, builds on forms of protectiveness, which are frequently correlated with women's roles in the family and include love and empathy. Women leaders have feminine qualities that will make it easier for them to look after their people. ${ }^{21}$

The pandemic brought by the Covid-19 had a massive impact on political leadership as people now see the differences of male and female world leaders. People could not but compare the leadership styles of men and women. The question of which is more effective - protective masculinity or protective femininity - is put to the limelight.

There has been actually a lot of discussion about how women led better than men before and during the Covid-19 crisis. Surprisingly, a study conducted between March and June of 2020 shows that women were viewed as more effective leaders by those who work with them. ${ }^{22}$ And in times of crisis, perceived feminine leadership qualities are often valued more compare to its male counterpart. ${ }^{23}$ The current pandemic health-related existence, combined with lockdown's emphasis on confinement to the (feminized) domain of the home, has arguably encouraged the leveraging of women's role to an even greater degree. ${ }^{24}$

It is also argued that countries led by women have six times fewer deaths than countries led by men. ${ }^{25}$ And research findings suggest that this is likely due to women's more proactive and coordinated policy initiatives. ${ }^{26}$ Furthermore, the caring, empathic, and relatable leadership styles of female leaders make the public feel more optimistic about the future. In mid-March 2020, policy speeches given by female world leaders contributed to the global impression that women chief executives were better at managing the spread of the virus than men. ${ }^{27}$

For Melinda Gates, women should be remembered as builders of a better future, not just victims of a broken world, in order for people to recover from the pandemic in all of its dimensions. ${ }^{28}$ Women leaders Angela Merkel of Germany, Jacinda Ardern of New Zealand, and Tsai

\footnotetext{
${ }^{19}$ An example of the portrayal of protective masculinity is the promise made by President Rodrigo Duterte that in three to six months, he will stop criminality and illegal drugs in the Philippines. Because of his motto, "change is coming", he was voted for by more than 16 million Filipino people as the $16^{\text {th }}$ President of the country. Another example is when former American President Donald Trump depicted himself as the strong alpha male who would defend Americans from threats such as undesirable immigrants and the loss of jobs overseas to "make America great again."

${ }^{20}$ Johnson Carol and Blair Williams. "Gender and Political Leadership in a Time of COVID." Politics \& Gender 16, no. 4 (2020): 943-950. doi:10.1017/S1743923X2000029X.

${ }^{21}$ Ibid. $943-50$

${ }^{22}$ Zenger, J. and Folkman, J. (2020). Research: Women Are Better Leaders During a Crisis. Harvard Business Law. https://hbr.org/2020/12/research-women-are-better-leaders-during-a-crisis

${ }^{23}$ Michelle K. Ryan, S. Alexander Haslam, Thekla Morgenroth, Floor Rink, Janka Stoker and Kim Peters. "Getting on top of the glass cliff: Reviewing a decade of evidence, explanations, and impact." The Leadership Quarterly 27 no. 3 (2016): 446-445. https://doi.org/10.1016/j.leaqua.2015.10.008

${ }^{24}$ Johnson Carol and Blair Williams. Gender and Political Leadership in a Time of COVID. 943-950.

${ }^{25}$ Coscieme L., Fioramonti L., \& Trebeck K. (2020, May 26). Women in power: Countries with female leaders suffer six times fewer Covid deaths and will recover sooner from recession.

OpenDemocracy. https://www.opendemocracy.net/en/can-europe-make-it/women-power-countries-female-leaderssuffer-six-times-fewer-covid-deaths-and-will-recover-sooner-recession/

${ }^{26}$ Supriya Garikipati and Uma Kambhampati, "Leading the Fight Against the Pandemic: Does Gender 'Really' Matter?", SSRN, June 3, 2020, https://papers.ssrn.com/sol3/papers.cfm?abstract_id=3617953

${ }^{27}$ Amanda Taub. "Why Are Women-Led Nations Doing Better With Covid-19?", The New York Times, May 15, 2020, https://www.nytimes.com/2020/05/15/world/coronavirus-women-leaders.html

${ }^{28}$ Ellis, A. (2020). Building Forward Better - Why Women's Leadership Matters. International Leadership Association. https://theila.org/building-forward-better-why-womens-leadershipmatters/?gclid=Cj0KCQjw3duCBhCAARIsAJeFyPUECFKkS48dQiTysSOk9h_mwGDMZEy650Z9DGiWV19$\underline{\text { 6U1Oar7OcegaArzOEALw_wcB }}$
} 
Ing-wen of Taiwan can be the living testimonies of architects of a better world because of their excellent response to the pandemic.

\section{THE PANDEMIC RESPONSE OF GERMANY, NEW ZEALAND AND TAIWAN}

In Germany, as part of their pandemic response, Chancellor Angela Merkel often refers to Robert Koch Institute (RKI) surveillance data and uses epidemiological principles including reproduction rate as a motivator for social distancing policies. ${ }^{29}$ On the onset of the pandemic, Merkel also immediately declared that the federal states and the federal government had agreed to enact a "touch ban," restricting public meetings to two people (outside of families), requiring a physical distance of at least 5 feet (1.5 meters), and closing several businesses in order to contain the deadly virus. ${ }^{30}$

Overall, the nation has a robust health-care system, which contributed to their containment strategy's early success. Furthermore, the government's emphasis on gathering and evaluating data and transmitting the findings to the public has resulted in high levels of public support for the duration of the pandemic. Germany may not be considered a positive outlier in general, however, it has performed admirably in comparison to the majority of Europe's hard-hit countries. ${ }^{31}$

New Zealand's response to the coronavirus pandemic was the strongest in the world, and the country gives business leaders the most hope for potential investment. ${ }^{32}$ With no reported Covid-19 case yet, any foreigner arriving from or passing through China was announced to be denied entry in the country. Also, any citizen who returned from China had to isolate themselves for 14 days. Prime Minister Jacinda Ardern said the rules were the strictest in the world, and she would "make no apologies" for them. ${ }^{33}$

In the absence of a vaccine, New Zealand implemented a series of non-pharmaceutical treatments with the aim of eliminating COVID-19 cases. ${ }^{34}$ While other countries in the world were having a difficult job in battling with the deadly virus, New Zealand, through the leadership of Ardern remained calm and heavily relied in scientific data as basis for decisions and policies to be set out.

New Zealand's experience shows that, as much as stringency, efficient non-pharmaceutical approaches rely on quick decisions from health authorities, effective monitoring systems, and tailored testing strategies. ${ }^{35}$

Following the identification of the first infected individual in the country in January 21,2020 , Taiwan hastily embarked on a thorough investigation to monitor each patient's travel and communication history, assisting in the isolation and containment of the virus until it spread to the rest of the country. Aside from the tireless efforts of its public-health practitioners, the informed people have played an important role. Body temperature control

\footnotetext{
${ }^{29}$ The Editorial Board. Germany’s new coronavirus thinking. Wall Street Journal, May 14, 2020, https://www.wsj.com/articles/germanys-new-coronavirus-thinking-11589498695.

${ }^{30}$ Julia Hollingsworth, Jeni Marsh, Rob Picheta, Fernando Alfonso III, and Amir Vera. "March 22 coronavirus news". CNN. March 22, 2020,

https://edition.cnn.com/world/live-news/coronavirus-outbreak-03-22-20/h_0ff44fe3fd52f6ea7471206d0b7ff501.

${ }^{31}$ Max Roser, Hannah Ritchie, Esteban Ortiz-Ospina and Joe Hasell. "Coronavirus Pandemic (COVID-19)". OurWorldInData.org, updated daily, https://ourworldindata.org/coronavirus/country/germany?country= DEU

32 Martin Farrer. "New Zealand's Covid-19 response the best in the world, say global business leaders" The Guardian, October 8 , 2020, https://www.theguardian.com/world/2020/oct/08/new-zealands-covid-19-response-the-best-in-the-world-say-global-businessleaders

${ }^{33}$ Anna Jones. "How did New Zealand become Covid-19 free?” BBC News, July 10, 2020, https://www.bbc.com/news/world-asia-53274085

${ }^{34}$ Ministry of Health. "COVID-19 Health and Disability System Response Plan." (2020).

${ }^{35}$ Alexis Roberts. "Lessons from New Zealand's Covid-19 outbreak response", The Lancet Public Health 5, no. 11 (2020):e569-e570, https://doi.org/10.1016/S2468-2667(20)30237-1
} 
and disinfection measures have been implemented by private companies, franchises, as well as apartment complexes to complement government efforts in public spaces. ${ }^{36}$

As of 2020, Taiwan has one of the lowest mortality rates among high-income countries, and the disease was initially eliminated in April without the need for a lockdown. ${ }^{37}$ Taiwan's active response to COVID-19 has resulted in relatively low cases and mortality up until August 2020. This positive outcome reflected its pre-COVID-19 disease outbreak readiness, which included a dedicated national public health department and infrastructure, as well as integrated manual and digital solutions to support key role coordination. ${ }^{38}$

To sum it up, there are two key antecedents ${ }^{39}$ for Taiwan's success in its pandemic-response. The first key, and perhaps most important factor in Taiwan's COVID-19 response, was its strong institutions. Taiwan had not only the capability but also the expertise to deal with an outbreak as it experienced battling with the severe acute respiratory syndrome or SARS eighteen (18) years ago. The second key or factor that accelerated Taiwan's response was its historic exclusion from the World Health Organization (WHO). Taiwan's absence from the WHO prevents local health officials from organizing and sharing information on a government-to-government level, furthering Taiwan's isolation. The silver lining of Taiwan's exclusion is that it was forced to rely on itself as it could not afford to wait for the WHO or other countries to act or provide guidance.

No country in the world has been spared from the deadly virus. No world leader is in ease in leading his or her country in its pandemic response. However, the cases of Germany, New Zealand and Taiwan exemplify that women leader are in control and outperforming their male counterparts.

\section{ACKNOWLEDGING WOMEN LEADERSHIP}

In the political arena, women leaders are doing exceptionally well. They are effective agents of change. Their ability to make decisions has already been recognized in a variety of fields. It is past time for the world to accept the advantages of women in positions of leadership.

Women leaders, according to organizational studies, can bring a specific set of leadershiprelated characteristics, qualities, and behaviors to the workplace, which can benefit their organizations. ${ }^{40}$ However, success in women leadership will only be realized when social barriers such as gender-based discrimination, implied bias, unfair treatment, women objectification, and the like will no longer be committed.

Women's advancement into leadership positions is gaining traction. People will no longer find it surprising that a woman is in power when they see more women competently acting as leaders. ${ }^{41}$

\footnotetext{
36 Tsai Ing-wen. "President of Taiwan: How My Country Prevented a Major Outbreak of COVID-19." Time, April 16, 2020, https://time.com/collection/finding-hope-coronavirus-pandemic/5820596/taiwan-coronavirus-lessons/

${ }^{37}$ Taiwan Centers for Disease Control. "COVID-19 (2019-nCoV)," accessed April 5, 2021, https://sites.google.com/cdc.gov.tw/2019-ncov/taiwan

38 Jennifer Summers, Hao-Yuan Cheng, Hsien-Ho Lin, Lucy Telfar Barnard, Amanda Kvalsvig, Nick Wilson, and Michael G. Baker. "Potential lessons from the Taiwan and New Zealand health responses to the COVID-19 pandemic." The Lancet Regional Health-Western Pacific 4, no. 100044, (2020):1-6, DOI: https://doi.org/10.1016/j.lanwpc.2020.100044

${ }^{39}$ Lev Nachman. “Taiwan's Covid-19 Triumph,” The Diplomat, February 1, 2021, https://thediplomat.com/2021/01/taiwans-covid-19-triumph/

${ }^{40}$ Lynn R. Offermann, and Kira Foley. "Is There a Female Leadership Advantage?" Oxford Research Encyclopedia of Business and Management. 28 Feb. 2020, https://oxfordre.com/business/view/10.1093/acrefore/9780190224851.001.0001/acrefore-9780190224851-e-61

${ }^{41}$ Alice H. Eagly. "Once more: The rise of female leaders: How gender and ethnicity affect the electability and success of women as political leaders." American Psychological Association, September 8, 2020, https://www.apa.org/research/action/female-leaders
} 
Overall, women are ascending to positions of leadership not only in organizations but also in politics. And various researches show that these women are not clones of male leaders in general.

In terms of leadership, they are traditionally more participative and democratic than men. They tend to prioritize the public good in their goals, which is in line with their more compassionate and egalitarian values. It is to note that women's growing engagement in leadership can be facilitated by the inherent justice that is highly respected in democratic societies, as well as the expertise of women who compete for political office and other leadership positions. ${ }^{42}$

\section{CONCLUSION}

Both men and women have the capability to lead. Gender is not a hindrance for a leader to be effective and efficient. It is important to note that some women leaders have actually shown impressive governance before and during the Covid-19 crisis.

In reality, due to the political double bind, women leaders have gendered incentives to pay attention to both masculine and feminine leadership traits. During a pandemic crisis, they have the capability to care for the national family while also taking proactive steps including closing borders, issuing executive orders, and resolving security-related pandemic concerns. ${ }^{43}$ But what is more important is that societies must transform into egalitarian ones in order that equality among all will be the trend.

There is a saying that women can do what men can do, and do it in a 5-inch heels. She can do better what a man can. And no matter how the world would see the woman as an inferior class to man, maybe in the end, we may all realize that the last man standing is a WOMAN! Thus, let HER lead!

\footnotetext{
42 Ibid.

${ }^{43}$ Leah Windsor, Gina Yannitell Reinhardt, Alistair Windsor, Robert Ostergard, Susan Allen, Courtney Burns, Jarod Giger, and Reed wood. "Gender in the time of COVID-19: Evaluating national leadership and COVID-19 fatalities", PLoS ONE 15, 12 (2020): e0244531. https://doi.org/10.1371/journal.pone.0244531
} 


\section{REFERENCES}

Alexis Roberts. "Lessons from New Zealand's Covid-19 outbreak response", The Lancet Public Health 5, no. 11 (2020):e569-e570, https://doi.org/10.1016/S2468-2667(20)30237-1

Alice H. Eagly. "Once more: The rise of female leaders: How gender and ethnicity affect the electability and success of women as political leaders." American Psychological Association, September 8, 2020, https://www.apa.org/research/action/female-leaders

Amanda Taub. “Why Are Women-Led Nations Doing Better With Covid-19?”, The New York Times, May 15, 2020, https://www.nytimes.com/2020/05/15/world/coronavirus-women-leaders.html

Anna Jones. "How did New Zealand become Covid-19 free?” BBC News, July 10, 2020, https://www.bbc.com/news/world-asia-53274085

Christine Ro, "Why do we still distrust women leaders?” BBC, January 19, 2021, https://www.bbc.com/worklife/article/20210108-why-do-we-still-distrust-women-leaders.

Coscieme L., Fioramonti L., \& Trebeck K. (2020, May 26). Women in power: Countries with female leaders suffer six times fewer Covid deaths and will recover sooner from recession.

OpenDemocracy. https://www.opendemocracy.net/en/can-europe-make-it/women-power-countries-femaleleaders-suffer-six-times-fewer-covid-deaths-and-will-recover-sooner-recession/

Eagly, Alice H. "Sex differences in social behavior: A social-role interpretation", Psychology Press, 2013.

Ellis, A. (2020). Building Forward Better - Why Women's Leadership Matters. International Leadership Association. https://theila.org/building-forward-better-why-womens-leadershipmatters/?gclid=Cj0KCQjw3duCBhCAARIsAJeFyPUECFKkS48dQiTysSOk9h_mwGDMZEy650Z9DGiWV196U1Oar7OcegaArzOEALw_wcB

Gelaye Debebe and Sandy Nunn, eds., "Navigating the double bind: Transformations to balance contextual responsiveness and authenticity in women's leadership development”, Cogent Business \& Management, 4:1 (2017): 1-28, DOI: https://doi.org/10.1080/23311975.2017.1313543

Georgina Waylen, Karen Celis, Johanna Kantola, and S. Laurel Weldon, eds., The Oxford Handbook of Gender and Politics (Oxford: Oxford University Press, 2013), 3. DOI: 10.1093/oxfordhb/9780199751457.013.0034

Jennifer Summers, Hao-Yuan Cheng, Hsien-Ho Lin, Lucy Telfar Barnard, Amanda Kvalsvig, Nick Wilson, and Michael G. Baker. "Potential lessons from the Taiwan and New Zealand health responses to the COVID-19 pandemic." The Lancet Regional Health-Western Pacific 4, no. 100044, (2020):1-6, DOI: https://doi.org/10.1016/j.lanwpc.2020.100044

Johnson Carol and Blair Williams. "Gender and Political Leadership in a Time of COVID.” Politics \& Gender 16, no. 4 (2020): 943-950. doi:10.1017/S1743923X2000029X.

Johnson Carol and Blair Williams. Gender and Political Leadership in a Time of COVID. 943-950.

Julia Hollingsworth, Jeni Marsh, Rob Picheta, Fernando Alfonso III, and Amir Vera. "March 22 coronavirus news". CNN. March 22, 2020, https://edition.cnn.com/world/live-news/coronavirus-outbreak-03-2220/h_Off44fe3fd52f6ea7471206d0b7ff501

Kantar, “The Reykjavik Index for Leadership 2020/2021,” accessed April 5, 2021, https://www.kantar.com/campaigns/reykjavik-index/.

Karen Lema, "Philippines' Duterte says presidency no job for a woman,” Reuters, January 14, 2021, https://www.reuters.com/article/us-philippines-duterte-idUSKBN29J21U

Leah Windsor, Gina Yannitell Reinhardt, Alistair Windsor, Robert Ostergard, Susan Allen, Courtney Burns, Jarod Giger, and Reed wood. "Gender in the time of COVID-19: Evaluating national leadership and COVID-19 fatalities", PLOS ONE 15, 12 (2020): e0244531. https://doi.org/10.1371/journal.pone.0244531

Lev Nachman. “Taiwan’s Covid-19 Triumph,” The Diplomat, February 1, 2021, https://thediplomat.com/2021/01/taiwans-covid-19-triumph/

Lynn R. Offermann, and Kira Foley. "Is There a Female Leadership Advantage?" Oxford Research Encyclopedia of Business and Management. 28 Feb. 2020, https://oxfordre.com/business/view/10.1093/acrefore/9780190224851.001.0001/acrefore-9780190224851-e-61

Martin Farrer. "New Zealand's Covid-19 response the best in the world, say global business leaders" The Guardian, October 8, 2020, https://www.theguardian.com/world/2020/oct/08/new-zealands-covid-19-response-the-best-inthe-world-say-global-business-leaders

Max Roser, Hannah Ritchie, Esteban Ortiz-Ospina and Joe Hasell. "Coronavirus Pandemic (COVID-19)". OurWorldInData.org, updated daily, https://ourworldindata.org/coronavirus/country/germany?country= DEU

Merriam-Webster (Merriam-Webster, Incorporated), s.v. "Politics," https://www.merriamwebster.com/dictionary/politics 
Michelle K. Ryan, S. Alexander Haslam, Thekla Morgenroth, Floor Rink, Janka Stoker and Kim Peters. "Getting on top of the glass cliff: Reviewing a decade of evidence, explanations, and impact." The Leadership Quarterly 27 no. 3 (2016): 446-445. https://doi.org/10.1016/j.leaqua.2015.10.008

Ministry of Health. "COVID-19 Health and Disability System Response Plan." (2020).

Monica Ferrín, Marta Fraile, Gema García-Albacete, and Raul Gómez, “The gender gap in political interest revisited." International Political Science Review, 41 no. 4: 473489. https://doi.org/10.1177/0192512119860260

Morgan, B. (2021, March 7). 15 Of The World's Most Inspiring Female Leaders. Forbes. https://www.forbes.com/sites/blakemorgan/2021/03/07/15-of-the-worlds-most-inspiring-femaleleaders/?sh=15c8adef3e6e

Online Etymology Dictionary, s.v. "Politics," https://www.etymonline.com/word/politic?ref=etymonline_crossreference\#etymonline_v_17575

Roxanne Dunbar, "Female Liberation as the Basis for Social Revolution," in Sisterhood is Powerful, ed R. Morgan (New York: Vintage Books A Division of Random House, 1970), 477-494.

Sidney Verba, Nancy Burns, and Kay Lehman Schlozman, "Knowing and Caring about Politics: Gender and Political Engagement.” The Journal of Politics, 59 no. 4 (1997): 1051-1072, http://www.jstor.org/stable/2998592

Supriya Garikipati and Uma Kambhampati, “Leading the Fight Against the Pandemic: Does Gender 'Really’ Matter?”, SSRN, June 3, 2020, https://papers.ssrn.com/sol3/papers.cfm?abstract_id=3617953

Taiwan Centers for Disease Control. "COVID-19 (2019-nCoV),” accessed April 5, 2021, https://sites.google.com/cdc.gov.tw/2019-ncov/taiwan

The Editorial Board. Germany's new coronavirus thinking. Wall Street Journal, May 14, 2020, https://www.wsj.com/articles/germanys-new-coronavirus-thinking-11589498695.

Tsai Ing-wen. "President of Taiwan: How My Country Prevented a Major Outbreak of COVID-19." Time, April 16, 2020, https://time.com/collection/finding-hope-coronavirus-pandemic/5820596/taiwancoronavirus-lessons/

UN Women, "Facts and figures: Women's leadership and political participation,” accessed April 5, 2021, https://www.unwomen.org/en/what-we-do/leadership-and-political-participation/facts-and-figures

Wagner, Claire. "Sexual Politics." The Australian Quarterly 43, no. 4 (1971): 121-25. Accessed April 5, 2021. doi: $10.2307 / 20634474$.

Zenger, J. and Folkman, J. (2020). Research: Women Are Better Leaders During a Crisis. Harvard Business Law. https://hbr.org/2020/12/research-women-are-better-leaders-during-a-crisis 